\title{
Efektifitas alat pengering tipe box gabah padi (Oryza Sativa L.) terhadap tingkat kadar air
}

\author{
Raybian Nur ${ }^{1^{*}}$, Muhammad Arsad Al Banjari ${ }^{2}$ \\ 1,2Program Studi D3 Teknik Otomotif Politeknik Hasnur \\ Jl. Brigjen Hasan Basri, Barito Kuala 70582, Kalimantan Selatan-Indonesia \\ raybianbyan@gmail.com
}

\begin{abstract}
Barito Kuala is a regency located in South Kalimantan Province. Most people in Barito Kuala Regency are rice farmers. When the rice is harvested, the harvest is traditionally dried by using radiation from the sun. However, the utilization of solar energy cannot always be used for example due to weather effects. Harvested rice has a moisture content of 21-26\%. According to the SNI standard (Indonesian National Standard), the maximum moisture content in rice grain to be marketed is $14 \%$. The purpose of this research is to make a tool and measure the level of effectiveness for drying small-scale rice grain. testing is done by taking a portion of rice grain then put into a box type rice grain dryer and compared with drying that utilizes solar energy. The results of the data obtained that every 5 minutes have a difference in the decrease in water content of $2.18 \%$ for 20 minutes with an initial water content of $15.3 \%$.
\end{abstract}

Keywords : Rice grain dryer, drying media type, moisture level.

\begin{abstract}
Abstrak
Barito Kuala merupakan Kabupaten yang letaknya berada pada Provinsi Kalimantan Selatan. Sebagian besar masyarakat di Kabupaten Barito Kuala adalah petani padi. Saat pasca panen padi, hasil dari panen tersebut dikeringkan secara tradisional dengan memanfaatkan radiasi dari matahari. Akan tetapi, pemanfaatan energi matahari tidak selalu bisa digunakan misalnya akibat pengaruh cuaca. Gabah padi hasil panen memiliki tingkat kadar air $21-26 \%$. Menurut standar SNI (Standar Nasional Indonesia) tingkat kadar air maksimum pada gabah padi untuk dipasarkan adalah $14 \%$. Tujuan dari penelitian ini adalah membuat alat dan mengukur tingkat efektifitas untuk mengeringkan gabah padi skala kecil. pengujian dilakukan dengan mengambil sebagian gabah padi kemudian dimasukkan kedalam pengering gabah padi tipe box dan dibandingkan dengan pengeringan yang memanfaatkan energi matahari. Hasil data diperoleh bahwa setiap 5 menit memiliki selisiih penurunan kadar air sebesar 2,18\% selama 20 menit dengan kadar air awal adalah 15,3\%.
\end{abstract}

Kata kunci: Alat pengering gabah padi, jenis media pengering, tingkat kadar air.

\section{Pendahuluan}

Negara Indonesia makanan pokok utama bagi masyarakatnya adalah beras, beras sendiri berasalkan dari hasil pertanian padi dalam bentuk butiran padi (Gabah). Bentuk gabah sendiri seperti biji yang dilapisi oleh sekam. Massa dari gabah pada kadar air $0 \%$ adalah antara $12-44 \mathrm{mg}$, sedangkan massa dari kulit luar yaitu sekam rata-rata sebesar 20\% dari massa gabah [5].
Secara umum, pengeringan gabah dibedakan menjadi 2 jenis yaitu secara alami (memanfaatkan energi matahari) dan buatan (menggunakan alat bantu pengeringan) [2]. Pengeringan gabah secara alami adalah pengeringan yang memanfaatkan terik matahari dengan menjemur langsung di bawah terik matahari secara langsung, sedangkan pengeringan buatan adalah pengeringan dengan menggunakan alat pengering [6]. Jenis 
pengeringan yang sering digunakan oleh para petani padi adalah pengeringan secara tradisional yaitu pemanfaatan terik matahari [8]. Untuk mengetahui apakah gabah sudah kering atau memiliki kadar air rendah yaitu dengan cara menggigit butiran gabah padi. Apabila terdengar bunyi "kletik", hal tersebut menunjukkan gabah kering dan siap disimpan [3]. Pengujian kekeringan tersebut tergolong akurat karena hanya berdasarkan pengalaman petani tanpa mengetahui kadar air sebenarnya yang terkandung.

Berdasarkan pemaparan yang diuraikan di atas, maka dilakukan penelitian tentang efektifitas penggunaan alat pengering gabah tipe box dibandingkan dengan pengeringan secara tradisional yang memanfaatkan panas matahari.

\section{Tinjauan Pustaka}

Biji tanaman padi (Oryza Sativa L.) atau sering disebut gabah terdiri atas biji yang terbungkus oleh sekam, dan biji padi inilah yang sering kita sebut beras. Beras merupakan sumber protein dan energi. Selain mengandung protein dan energi beras juga mengandung vitamin (pada bagian aleuron) [1].

Tabel 1. Komposisi gizi beras giling dalam 100 gram

\begin{tabular}{clc}
\hline No & $\begin{array}{c}\text { Komposisi gizi beras } \\
\text { giling }\end{array}$ & Jumlah \\
\hline 1 & Energi (Kal) & 354,0 \\
\hline 2 & Protein $(\mathrm{g})$ & 7,1 \\
\hline 3 & Lemak $(\mathrm{g})$ & 0,5 \\
\hline 4 & Karbohidrat $(\mathrm{g})$ & 77,8 \\
\hline 5 & Kalsium $(\mathrm{mg})$ & 8,0 \\
\hline 6 & Fosfor $(\mathrm{mg})$ & 104,0 \\
\hline 7 & Besi $(\mathrm{mg})$ & 1,2 \\
\hline 8 & Air $(\mathrm{g})$ & 14,0 \\
\hline
\end{tabular}

Massa dari gabah pada kadar air 0\% adalah antara 12 - $44 \mathrm{mg}$, sedangkan massa dari kulit luar yaitu sekam rata-rata sebesar $20 \%$ dari massa gabah [5].

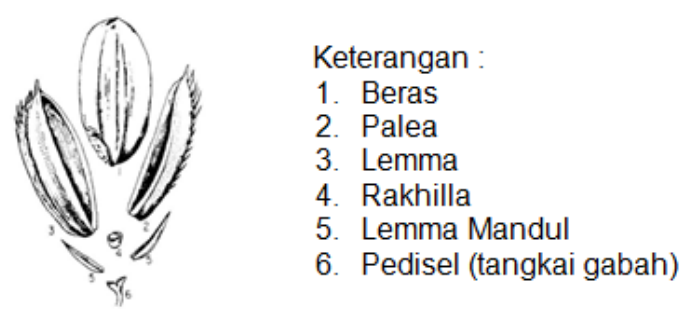

Gambar 1. Struktur gabah

Setelah musim panen selesai, para petani khususnya di Kabupaten Barito Kuala melakukan penjemuran gabah. Biasanya penjemuran dilaksanakan di lahan yang luas seperti lahan pertanian atau halaman rumah agar seluruh gabah kering, penjemuran dilakukan di bawah sinar matahari. Tidak sedikit petani yang gabahnya rusak dikarenakan terkena air hujan pada saat menjemur atau memasuki musim hujan sehingga tidak ada waktu untuk melakukan penjemuran gabah.

\section{Metode Penelitian}

Untuk mencapai hasil yang dikehendaki maka penelitian ini menggunakan metode eksperimental. Dalam metode ini, hal yang dilakukan adalah mengamati perubahan kadar air yang terjadi pada gabah dengan membandingkan jenis pengeringan secara tradisional dengan pengeringan menggunakan alat yaitu tipe box.

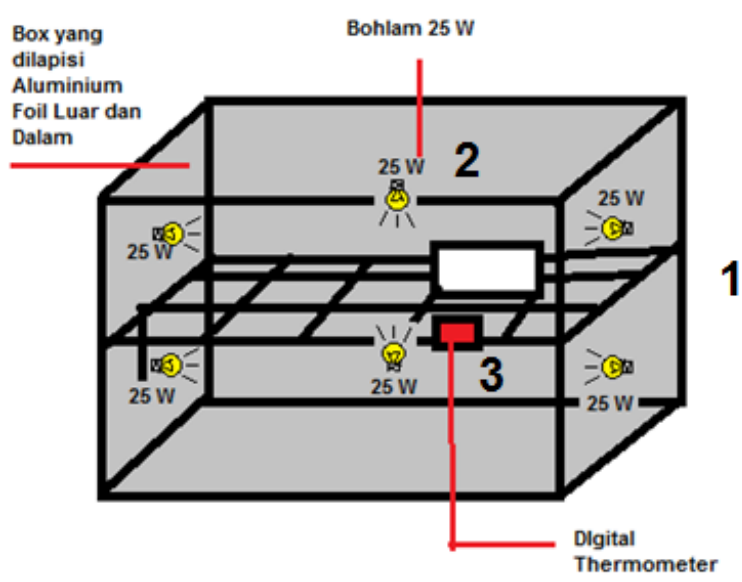

Gambar 2. Desain alat pengering tipe box

Keterangan:

1. Box Pengering

2. Bola lampu 25 Watt

3. Digital Thermometer beserta display 


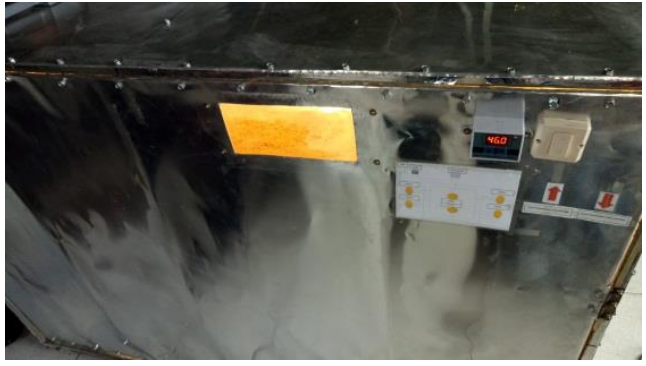

Gambar 3. Pengering tipe box

Dalam pengambilan data, bohlam yang digunakan memiliki daya 25 Watt per bohlam dengan jumlah bohlam 6 Bohlam, gabah yang digunakan diambil untuk sampel sebanyak $5 \mathrm{~kg}$ setiap pengujian, dan pengujian dilakukan sebanyak 3 kali pengulangan.

\section{Hasil dan Pembahasan}

Pada proses pengambilan data, pengeringan gabah dilakukan dengan 2 (dua) cara yaitu dengan cara memanfaatkan energi matahari (tradisional) dan box pengering, maka didapatkan hasil yang berbeda diantaranya dari aspek waktu yang diperlukan dan tingkat kadar air gabah. Berikut merupakan hasil pengambilan data dari jenis media pengering tersebut.

1. Perhitungan daya radiasi

$$
\mathrm{P}=\mathrm{e} \sigma \mathrm{AT} 4
$$

Keterangan:

$\mathrm{P} \quad=$ Daya yang diradiasikan (watt)

$\mathrm{e} \quad=$ Emisivitas suatu benda

$\sigma \quad=$ Konstanta Stefan $(5,6703 \times 10-8$ $\mathrm{W} / \mathrm{m} 2 \mathrm{~K} 4)$.

A = Luas suatu benda yang memancarkan radiasi $(\mathrm{m} 2)$

$\mathrm{T} \quad=$ Suhu mutlak $(\mathrm{K})$

Nilai emisivitas e sebuah benda berdasarkan pada warna permukaan benda tersebut. Permukaan sebuah benda yang berwarna hitam sempurna memiliki nilai e $=1$, sedangkan untuk benda yang memiliki warna putih sempurna nilai $\mathrm{e}=0$. sehingga nilai emisivitas e secara umum adalah $0<\mathrm{e}$ $<1$.
Persamaan emisivitas sebagai berikut

Keterangan:

$$
e_{x}=\frac{R_{x}}{R_{H}}
$$

$\mathrm{R}_{\mathrm{H}}=$ nilai hambatan warna hitam

$\mathrm{R}_{\mathrm{X}}=$ nilai hambatan warna tertentu

$\mathrm{e}_{\mathrm{H}}=$ emisivitas warna hitam

$\mathrm{e}_{\mathrm{x}}=$ emisivitas warna tertentu

Untuk mengetahui nilai hambatan warna untuk menentukan emisitas warna, maka perlunya melakukan pengukuran nilai hambatan warna dengan menggunakan multimeter analog. Hasil pengukuran tersebut dituangkan ke dalam tabel berikut:

Tabel 2. Emisivitas warna

\begin{tabular}{clcc}
\hline No & \multicolumn{1}{c}{ Warna } & $\begin{array}{c}\text { Rata- } \\
\text { rata }\end{array}$ & $\begin{array}{c}\text { Standar } \\
\text { Deviasi }\end{array}$ \\
\hline 1 & $\begin{array}{l}\text { Ungu (purple } \\
\text { comet) }\end{array}$ & 0,91 & 0,019 \\
\hline 2 & $\begin{array}{l}\text { Hijau (going } \\
\text { green) }\end{array}$ & 0,84 & 0,023 \\
\hline 3 & $\begin{array}{l}\text { Biru (true } \\
\text { blue) }\end{array}$ & 0,77 & 0,024 \\
\hline 4 & $\begin{array}{l}\text { Merah (talk } \\
\text { of the town) }\end{array}$ & 0,66 & 0,011 \\
\hline 5 & $\begin{array}{l}\text { Hijau muda } \\
\text { (apple } \\
\text { martini) }\end{array}$ & 0,61 & 0,013 \\
\hline 6 & $\begin{array}{l}\text { Biru muda } \\
\text { (sky blue) }\end{array}$ & 0,54 & 0,020 \\
\hline 7 & $\begin{array}{l}\text { Jingga } \\
\text { (orange } \\
\text { torch) }\end{array}$ & 0,50 & 0,018 \\
\hline 8 & $\begin{array}{l}\text { Coklat muda } \\
\text { (pastry puff) }\end{array}$ & 0,46 & 0,021 \\
\hline 9 & $\begin{array}{l}\text { Kuning } \\
\text { (absolute } \\
\text { yellow) }\end{array}$ & 0,37 & 0,013 \\
\hline $10 \begin{array}{l}\text { Merah muda } \\
\text { (crystal pink) }\end{array}$ & 0,24 & 0,012 \\
\hline Swer Suslatid 2018 & \\
\hline
\end{tabular}

Sumber: Susilawati,dkk 2018 
Tabel 3. Emisivitas Permukaan logam

\begin{tabular}{lll}
\hline No & \multicolumn{1}{c}{ Material } & Emissivity \\
\hline 1 & Aluminium Foil & 0,07 \\
\hline 2 & Polished aluminium & 0,82 \\
\hline 3 & Polished copper & 0,03 \\
\hline 4 & Polished gold & 0,03 \\
\hline 5 & Polished silver & 0,02 \\
\hline 6 & $\begin{array}{l}\text { Polished stainless } \\
\text { steel }\end{array}$ & 0,17 \\
\hline 7 & Black paint & 0,98 \\
\hline 8 & White paint & 0,90 \\
\hline 9 & White paper & $0,92-0,97$ \\
\hline 10 & Asphalt pavement & $0,85-0,93$ \\
\hline 11 & Red brick & $0,93-0,96$ \\
\hline 12 & Human skin & 0,95 \\
\hline 13 & Wood & $0,82-0,92$ \\
\hline 14 & Soil & $0,93-0,96$ \\
\hline 15 & Water & 0,96 \\
\hline 16 & Vegetation & $0,92-0,96$ \\
\hline Sumber: & Cengel, Meran, Thermodynamics an Engineering \\
aproach & &
\end{tabular}

Adapun warna dari gabah padi adalah kuning keemasan, sehingga diasumsikan untuk mengambil warna kuning dengan nilai emisivitas $\mathbf{0 , 3 7}$ dan nilai emisivitas aluminium foil adalah $\mathbf{0 , 0 7}$. Sehingga kita dapat menghitung daya radiasi.

2. Daya Radiasi Gabah

Diketahui:

$$
\begin{aligned}
& \mathrm{A}=50 \mathrm{~cm}^{2}=5 \times 10^{-3} \mathrm{~m}^{2} \\
& \mathrm{~T}=(35+273)=308 \mathrm{~K} \\
& \mathrm{e}=0,37 \\
& \sigma \quad=5,67 \times 10^{-8} \mathrm{~W} / \mathrm{m}^{2} \mathrm{k}^{4} \\
& \text { Maka, } \\
& \mathrm{P}=\mathrm{e} \sigma \mathrm{AT}^{4} \\
& =(0,37) \times\left(5,67 \times 10^{-8}\right) \times\left(5 \times 10^{-3}\right) \mathrm{x} \\
& \quad(308)^{4} \\
& =0,943969 \mathrm{~W}
\end{aligned}
$$

Sehingga energi radiasi yang dipancarkan oleh matahari tersebut pada setiap sekon kepada gabah padi adalah 0,94 Watt per satuan detik.
3. Daya Radiasi Aluminium Foil (Box Pengering)

Diketahui:

$$
\begin{aligned}
\mathrm{A}= & 7000 \mathrm{~cm}^{2}=0,7 \mathrm{~m}^{2} \\
\mathrm{~T}= & (35+273)=308 \mathrm{~K} \\
\mathrm{e}= & 0,37 \\
\sigma \quad= & 5,67 \times 10^{-8} \mathrm{~W} / \mathrm{m}^{2} \mathrm{k}^{4} \\
\text { Maka, } & \\
\mathrm{P}= & \text { e } \sigma \mathrm{AT}^{4} \\
= & (0,7) \times\left(5,67 \times 10^{-8}\right) \times\left(5 \times 10^{-3}\right) \mathrm{x} \\
& (308)^{4} \\
= & 1,76 \mathrm{~W}
\end{aligned}
$$

Sehingga energi radiasi yang dipancarkan oleh bohlam pijar tersebut pada setiap sekon kepada gabah padi adalah 1,76 Watt per satuan detik.

4. Perhitungan laju perpindahan panas secara radiasi pada pengeringan secara tradisional

Diketahui :

$$
\begin{aligned}
& \sigma=5,67 \times 10^{-8} \mathrm{~W} / \mathrm{m}^{2} \mathrm{k}^{4} \\
& \mathrm{~A}=50 \mathrm{~cm}^{2}=5 \times 10^{-3} \mathrm{~m}^{2} \\
& \mathrm{~T}_{1}=308 \mathrm{~K} \\
& \mathrm{~T}_{2}=295 \mathrm{~K}
\end{aligned}
$$

Maka,

$$
\begin{aligned}
\mathrm{q} & =\sigma \mathrm{A}\left(\mathrm{T}_{1}^{4}-\mathrm{T}_{2}^{4}\right) \\
= & \left(5,67 \times 10^{-8}\right) \times\left(5 \times 10^{-3}\right) \times\left(308^{4}-\right. \\
& \left.295^{4}\right) \\
= & 0,404222 \mathrm{~W}
\end{aligned}
$$

Sehingga perpindahan panas secara radiasi yang dipancarkan oleh matahari tersebut kepada gabah padi adalah 0,404 watt per satuan detik.

5. Perhitungan laju perpindahan panas secara radiasi pada pengeringan pada box pengering

Diketahui :

$$
\begin{aligned}
& \sigma=5,67 \times 10^{-8} \mathrm{~W} / \mathrm{m}^{2} \mathrm{k}^{4} \\
& \mathrm{~A}=50 \mathrm{~cm}^{2}=5 \times 10^{-3} \mathrm{~m}^{2} \\
& \mathrm{~T}_{1}=318 \mathrm{~K} \\
& \mathrm{~T}_{2}=295 \mathrm{~K}
\end{aligned}
$$

Maka, 


$$
\begin{aligned}
\mathrm{q} & =\sigma \mathrm{A}\left(\mathrm{T}_{1}{ }^{4}-\mathrm{T}_{2}{ }^{4}\right) \\
& =\left(5,67 \times 10^{-8}\right) \times\left(5 \times 10^{-3}\right) \times\left(318^{4}-\right. \\
& \left.295^{4}\right) \\
= & 0,752 \mathrm{~W}
\end{aligned}
$$

Sehingga perpindahan panas secara radiasi yang dipancarkan oleh matahari tersebut kepada gabah padi adalah 0,752 Watt per satuan detik.

\section{Proses Pengeringan Secara Tradisional}

Pada proses pengeringan ini memerlukan terpal sebagai wadah untuk menjemur gabah padi. Pada penelitian ini pengeringan dilakukan selama 20 Menit untuk pengambilan data.

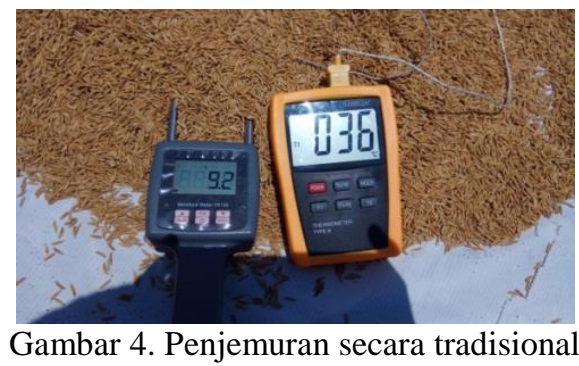

Mengukur tingkat kadar air yang terkandung pada gabah padi per 5 menit. Adapun data yang didapatkan terlampir

\begin{tabular}{|c|c|c|c|c|}
\hline \multirow[t]{2}{*}{ No } & \multirow{2}{*}{$\begin{array}{l}\text { Jumlah } \\
\text { gabah } \\
\text { (liter) }\end{array}$} & \multicolumn{2}{|c|}{$\begin{array}{c}\text { Kadar air }(\%) \\
\text { dalam pengeringan } \\
\text { (per } 5 \text { menit) }\end{array}$} & \multirow[t]{2}{*}{$\begin{array}{c}\text { Temperatur } \\
\left({ }^{\circ} \mathrm{C}\right)\end{array}$} \\
\hline & & Sebelum & Sesudah & \\
\hline 1 & 5 & 17,5 & 16,3 & 36 \\
\hline 2 & 5 & 17,5 & 12,8 & 36 \\
\hline 3 & 5 & 17,5 & 9,4 & 36 \\
\hline 4 & 5 & 17,5 & 8,8 & 36 \\
\hline
\end{tabular}
pada tabel berikut:

Tabel 4. Data hasil pengujian dengan penjemuran gabah secara tradisional

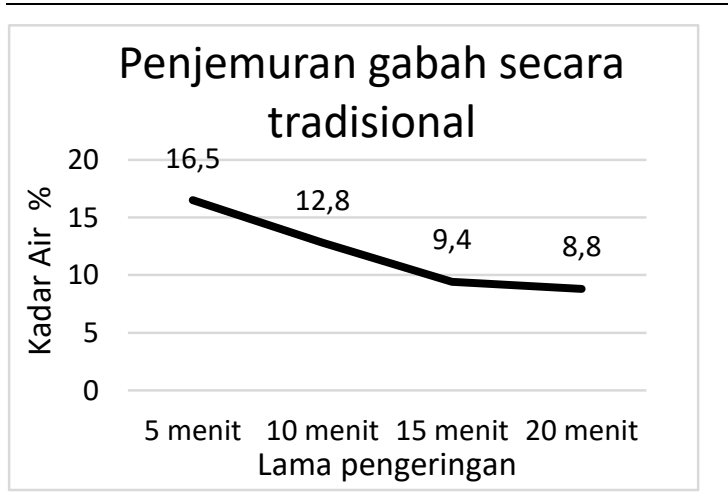

Gambar 5. Grafik pengujian dengan penjemuran gabah secara tradisional
Dari grafik Gambar 5 ditunjukkan bahwa rata-rata selisih penurunan kadar air pada pengeringan gabah per 5 menit secara tradisional adalah $2,18 \%$. Penurunan antara menit ke 5-10 memiliki tingkat penurunan kadar air tertinggi yaitu 3,7 \% dan semakin lama tingkat penurunan kadar air semakin sedikit, hal ini disebabkan oleh titik jenuh kandungan air pada gabah padi untuk menguap serta temperatur yang konstan sehingga daya penguapan yang terjadi sudah maksimal. Ulasan di atas di ungkapan kepada teori Jika suhu air makin tinggi maka pergerakan molekul dalam air akan semakin cepat dan terjadi tumbukan antar molekul, sehingga akan semakin mempercepat proses perpindahan massa dari cairan ke gas (berbanding lurus). Air akan menguap sehingga kadar uap air di udara naik (kelembaban naik) sampai mencapai titik jenuhnya.

7. Proses pengeringan dengan Box Pengering

Proses pengambilan data pengeringan gabah padi dengan menggunakan box pengering memerlukan beberapa tahapan diantaranya yaitu menghubungkan ke arus listrik dan memanaskan Box Pengering ke temperatur yang stabil yaitu $\pm 46{ }^{\circ} \mathrm{C}$.

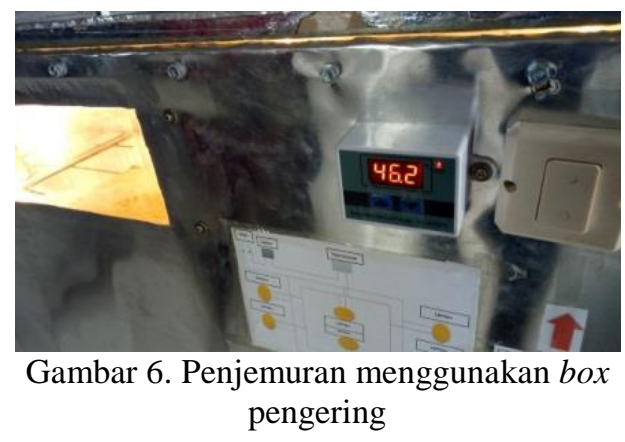

Mengukur kadar air gabah padi sebelum dimasukkan ke dalam box pengering. 


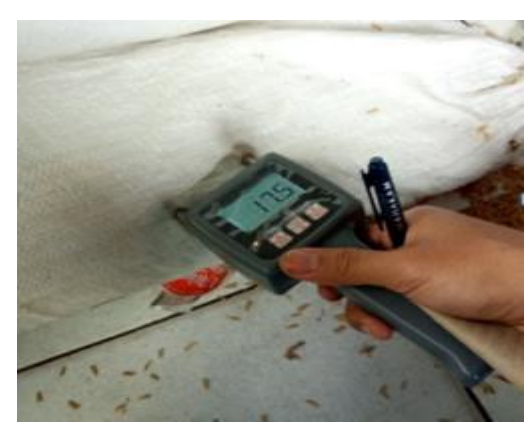

Gambar 7. Pengukuran tingkat kadar air gabah

Memasukan gabah Padi dan mengukur kadar air setiap 5 menit dengan durasi 20 menit.

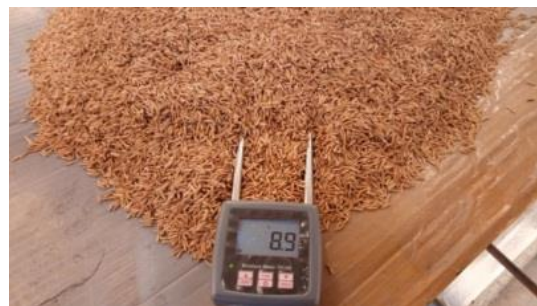

Gambar 8. Pengukuran tingkat kadar air gabah pada box pengering

Hasil keseluruhan dalam pengambilan data pengeringan gabah padi menggunakan media box pengering terlampir ke dalam tabel berikut:

Tabel 3. Data hasil pengeringan menggunakan box pengering

\begin{tabular}{ccccc}
\hline No & $\begin{array}{c}\text { Jumlah } \\
\text { gabah } \\
\text { (liter) }\end{array}$ & \multicolumn{2}{c}{$\begin{array}{c}\text { Kadar air (\%) } \\
\text { dalam pengeringan } \\
\text { (per 5 menit) }\end{array}$} & \multirow{2}{*}{$\begin{array}{c}\text { Temperatur } \\
\left({ }^{0} \mathrm{C}\right)\end{array}$} \\
\cline { 3 - 4 } & 5 & Sebelum & Sesudah & \\
\hline 2 & 5 & 17,5 & 15,3 & 46 \\
\hline 3 & 5 & 17,5 & 12,2 & 46 \\
\hline 4 & 5 & 17,5 & 9,7 & 46 \\
\hline
\end{tabular}

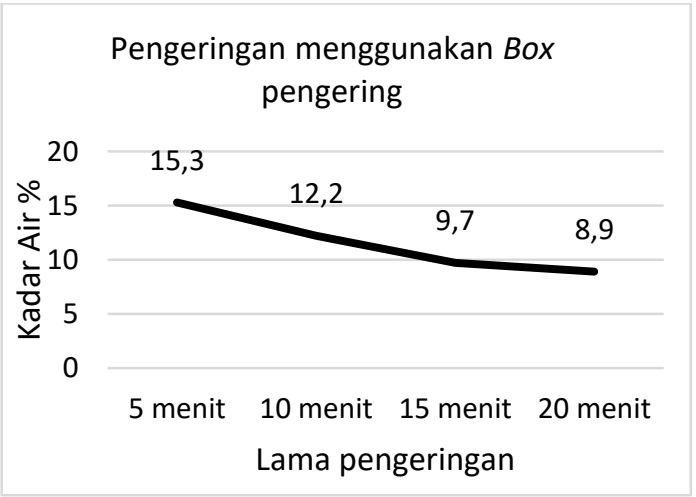

Gambar 9. Grafik pengujian dengan menggunakan box pengering
Dari grafik Gambar 9 ditunjukkan bahwa rata-rata selisih penurunan kadar air pada pengeringan gabah per 5 menit dengan box pengering adalah 2,18\% sama dengan nilai rata-rata selisih dari pengeringan secara tradisional. Hal ini disebabkan oleh temperatur yang konstan dalam proses pengeringan berlangsung. Penurunan antara menit ke 5-10 memiliki tingkat penurunan kadar air tertinggi yaitu 3,1\% dan semakin lama tingkat penurunan kadar air semakin sedikit.

\section{Kesimpulan}

Pengeringan dengan kadar air terendah dengan nilai $8,8 \%$ adalah pengeringan secara tradisional disusul dengan pengeringan dengan media box pengering dengan nilai kadar air 8,9\% dengan lama penjemuran 20 menit. Tingkat pengeringan yang besar terdapat pada media pengering secara tradisional yaitu 3,7 \%, akan tetapi selisih kecepatan pengeringan sama dengan pengeringan media box pengering. Semakin besar temperatur panas yang dihasilkan semakin cepat penguapan terjadi. Penggunaan alat pengering gabah padi tipe box sangat efektif untuk mengeringkan gabah padi dilihat dari hasil pengurangan kadar air tidak jauh beda dibandingkan dengan pengeringan secara tradisional (memanfaatkan energi matahari).

\section{Referensi}

[1] Alfina, dkk. 2013. Evaluasi mutu beras dan tingkat kesesuaian penanganannya (studi kasus di kabupaten karanganyar). Jurnal Litbang Provinsi Jawa Tengah, Volume 11 Nomor 1 - Juni.

[2] Ersi Selparia, Maksi Ginting. Pembuatan dan Pengujian Alat Untuk Menentukan Konduktivitas Plat Seng, Multiroof dan Asbes, Universitas Riau, 2015.

[3] Figiarto, dkk. 2012. Peningkatan kualitas gabah dengan proses pengeringan menggunakan zeolit 
alam pada unggun terfluidisasi. Jurnal teknologi Kimia dan Industri, Vol. 1, No. 1, Hal 206-212.

[4] Lestari, dkk. 2007. Uji daya hasil pendahuluan dan mutu beras 21 padi hibrida harapan preliminary yield trials and grain quality of 21 promissing hybrid rice. Balai besar penelitian tanaman padi, Bogor.

[5] Mungara, dkk. 2013. Analisis pertumbuhan dan hasil padi sawah (oryza sativa l.) Pada sistem pertanian konvensional, transisi organik, dan organik. Vegetalika Vol. 2 No. 3, Hal 1-12.

[6] Novia, dkk. 2007. Rancang Bangun Alat Ukur dan Indikator Kadar Air Gabah Siap Giling Berbasis Mikrokontroler dengan Sensor Fotodioda. Jurnal Fisika Unand Vol. 5, No. 1. Padang

[7] Susilawati, dkk. 2018. Menghitung nilai emisivitas warna menggunakan miniatur ruang berbentuk silinder sebagai media pembelajaran fisika. PENDIPA Journal of Science Education, 20182 (2), 135-141.

[8] Totok Prasetyo, dkk. 2008. Pengaruh Waktu Pengeringan dan Tempering Terhadap Mutu Beras Pada Pengeringan Gabah Lapisan Tipis, Institut Pertanian Bogor, Bogor.

[9] Yeni E Maryana, dkk. 2015. Pengaruh Tempering Terhadap Perubahan Kadar Air dan Waktu Pada Pengeringan Gabah Dengan Sinar Matahari Di Lahan Pasang Surut Kabupaten Banyuasin, Balai Pengkajian Teknologi Pertanian, Sumatera Selatan.

[10] Yunus A Cengel, 2008. Heat transfer a practical approach 2 nd Edition, Mc graw hill companies.

[11] Yunus A Cengel, et al. 2008. Heat transfer a practical approach 3rd Edition, Mc graw hill companies. 